\title{
Pemanfaatan Enzim Papain dalam Pembuatan Pakan Ikan Lele serta Pengolahan Nugget Ikan Lele
}

\author{
Deivy Andhika Permata, Sahadi Didi Ismanto, dan Alfi Asben \\ Fakultas Teknologi Pertanian, Universitas Andalas, Kampus Limau Manis, Padang, 25163. Indonesia \\ E-mail: deivyandhikapermata@ae.unand.ac.id
}

Keywords: catfish, nugget, pellets, papain enzyme

Kata Kunci: lele, nugget, pakan, papain

\begin{abstract}
Kelompok Muda Berkarya is a fisheries business group engaged in catfish farming. Issues incurred by partners are the costs incurred to buy pellets and slow growth of catfish. Besides that, the Kelompok Muda Berkarya and homemakers of fishers on Vilagge Pulau Karam are also interested in getting training on the manufacture of catfish processed products. However, there is no information on how to process it. Thus, improvement was carried out using counseling and demonstration methods, assistance, monitoring, and evaluation. From the results of the activities carried out, improving the understanding of fostered partners in making fish feed by adding papain enzymes by $90 \%$ and making catfish nuggets by $100 \%$. The resulting pellets require low production costs and can be increased growth of catfish.
\end{abstract}

\begin{abstract}
ABSTRAK
Kelompok Muda Berkarya merupakan kelompok usaha nelayan yang bergerak dibidang budidaya ikan lele. Masalah yang dihadapi mitra adalah besarnya biaya yang dikeluarkan untuk membeli pelet serta pertumbuhan ikan lele yang lambat. Disamping itu Kelompok Usaha Muda Berkarya dan ibu-ibu rumah tangga nelayan di Nagari Pulau Karam juga tertarik untuk mendapatkan pelatihan mengenai pembuatan produk olahan ikan lele, namun belum mengetahui cara mengolahnya. Untuk mengatasi masalah tersebut dilakukan suatu pembinaan dengan metode persiapan dan sosialisasi, penyuluhan, demonstrasi, monitoring dan evaluasi. Dari hasil kegiatan yang dilakukan terjadi peningkatan pemahaman mitra binaan dalam pembuatan pakan ikan lele dengan penambahan enzim papain sebesar $90 \%$ dan pembuatan nugget ikan lele sebesar $100 \%$. Pelet yang dihasilkan membutuhkan biaya produksi yang murah dan dapat mempercepat pertumbuhan ikan lele.
\end{abstract}

\section{PENDAHULUAN}

Nagari Pulau Karam merupakan salah satu Nagari yang terdapat di Kecamatan Koto XI Tarusan, Kabupaten Pesisir Selatan. Selain kaya akan hasil perikanan laut, masyarakat di Nagari Pulau Karam juga melakukan budidaya ikan air tawar, antara lain lele, nila, dan gurami. Salah satu kelompok usaha nelayan yang bergerak di bidang budidaya ikan lele adalah Kelompok Muda Berkarya. Kelompok ini memiliki jumlah kolam sebanyak 12 buah dengan ukuran 2 m x 3 m sebanyak 8 buah dan $4 \mathrm{~m}$ x 6 m sebanyak 4 buah. Usaha yang dijalankan kelompok ini berupa menjual lele untuk konsumsi dan penyediaan bibit lele. Satu siklus pembibitan berlangsung selama 15 hari dengan pakan yang diberikan berupa cacing. Untuk menghasilkan 60.000 ekor 
bibit/bulan mitra binaan membutuhkan sebanyak 80 kaleng cacing dengan harga Rp. 25.000,/kaleng sehingga biaya yang dibutuhkan sebesar Rp. 2.000.000, bibit lele dijual dengan harga Rp. 100,-. Sementara itu untuk lele konsumsi baru dapat dipanen setelah berumur 3 bulan dengan berat $1 \mathrm{~kg}$ setara dengan 8 ekor lele. Total panen lele untuk konsumsi per bulan adalah $250 \mathrm{~kg}$ dengan harga jual Rp. 16.000,-/kg, sedangkan pakan yang dibutuhkan berupa pelet sebanyak $200 \mathrm{~kg} /$ bulan dengan harga per kilogram Rp. 12.000,-. Sehingga biaya yang dibutuhkan sebesar 7.200.000,-. Disamping itu untuk menekan biaya mitra binaan juga mengunakan kulit ayam untuk pakan lele. Sebelumnya Ketua Kelompok pernah mendapatkan pelatihan mengenai pembuatan pakan ikan lele namun belum pernah dicobakan.

Jika dilihat dari besaran biaya yang dikeluarkan untuk membeli pelet tentunya sangat merugikan mitra binaan. Untuk itu mitra binaan berharap adanya pendampingan dari pihak perguruan tinggi tentang pembuatan pelet, sehingga biaya pembelian pakan lele dapat dikurangi, disamping itu dapat tumbuh dengan cepat dalam waktu relatif singkat. Menurut Subandiyono dan Hastuti (2010), pertumbuhan terjadi apabila ada kelebihan energi setelah energi yang digunakan untuk pemeliharaan tubuh, metabolisme basal, dan aktivitas. Pertumbuhan akan terjadi apabila didukung dengan pemberian pakan sesuai dengan kebutuhan nutrisi ikan dan memiliki nilai kecernaan yang tinggi. Salah satu upaya yang dapat dilakukan adalah dengan penambahan ezim papain ke dalam pakan ikan lele. Papain merupakan enzim protease yang terdapat pada getah papaya. Enzim tersebut digunakan untuk menghidrolisis ikatan peptida pada protein. Diharapkan dengan penambahan papain pada pakan lele kecernaan protein akan lebih meningkat sehingga pertumbuhan lele dapat berlangsung dengan cepat dalam waktu yang relatif singkat.

Disamping itu Kelompok Usaha Muda Berkarya dan ibu-ibu rumah tangga nelayan di Nagari Pulau Karam juga tertarik untuk mendapatkan pelatihan mengenai pembuatan produk olahan dari ikan lele ataupun ikan laut hasil tangkapan nelayan sekitarnya. Diharapkan ikan lele yang dibudidayakan ataupun ikan hasil tangkapan di laut tidak hanya dijual dalam keadaan segar, namun juga dapat diolah menjadi produk yang bernilai jual, seperti nugget ikan, sosis ikan ataupun bakso ikan. Pada tahun 2012, tim pengabdian telah melakukan Pelatihan Pembuatan dan Wirausaha Produk Ikan Terestrukturisasi pada Keluarga Nelayan di Nagari Ampang Pulai, Kec. Koto XI Tarusan, tepatnya di Nagari tetangga, mendengar adanya pelatihan ini ibu-ibu nelayan di Nagari Pulau Karam juga tertarik untuk mendapatkan pelatihan yang serupa.

Kegiatan ini bertujuan untuk memberikan pemahaman mitra binaan dalam pemanfaatan enzim papain dalam pembuatan pakan ikan lele serta pengolahan lanjutan ikan lele menjadi nugget. Diharapkan dari kegiatan ini masalah mitra binaan dapat teratasi.

\section{METODE}

Kegiatan ini dilaksanakan di Nagari Pulau Karam Kecamatan Koto XI Tarusan, dengan tahapan kegiatan sebagai berikut:

1. Persiapan dan Sosialisasi

Pada tahapan ini dilakukan pendekatan kepada kelompok mitra binaan untuk menentukan masalah prioritas yang akan diselesaikan, mengurus administrasi terkait yang dibutuhkan dan mempersiapkan sarana dan prasarana pendukung yang dibutuhkan.

2. Penyuluhan

Penyuluhan dilakukan dengan cara memaparkan materi tentang pengolahan pakan ikan lele dengan memanfaatkan enzim papain dan pengolahan nugget ikan lele.

3. Demonstrasi

Tahapan ini dilakukan dengan cara memperagakan langsung bagaimana cara memproduksi pakan ikan lele dengan penambahan enzim papain dan pengolahan nugget ikan lele.

4. Monitoring dan Evaluasi

Untuk mengukur keberhasilan suatu program maka perlu dilakukan monitoring dan evaluasi dari kegiatan tersebut. Pada tahapan ini dilihat sejauh mana pemahaman dan keterampilan 
kelompok binaan dalam membuat pakan ikan lele dan nugget ikan lele. Disamping itu juga dibahas kedala apa saja yang dihadapi dan pemberian solusinya.

\section{HASIL DAN PEMBAHASAN}

Pada tahap awal telah diidentifikasi permasalahan yang dihadapi mitra, antara lain pada Kelompok Muda Berkarya, yakni pakan ikan lele yang diberikan masih dibeli dengan harga yang relatif mahal dan umur panen lele dengan kriteria bobot badan yang diharapkan masih tergolong lama. Pada ibu-ibu rumah tangga nelayan di Nagari Pulau Karam belum mengetahui bagaimana meningkatkan nilai tambah dari ikan segar. Pada kegiatan awal ini juga disepakati partisipasi mitra berupa penyediaan bahan baku, tenaga kerja, tempat untuk pertemuan serta koordinasi dalam pembimbingan proses.

Untuk memecahkan persolaan di atas, telah dilaksanakan kegiatan pengabdian masyarakat yang diikuti oleh mitra binaan berupa penyuluhan dan praktek pemanfaatan enzim papain dalam pembuatan pelet ikan lele serta pengolahan ikan lele menjadi nugget lele. Pembuatan pakan lele dilaksanakan dengan beberapan tahapan, meliputi pembuatan papain kasar dan pembuatan pakan ikan.

Pembuatan papain kasar (Permata, Ikwan, Aisman, 2016), dilakukan dengan cara menyadap getah pepaya muda pada pagi hari. Kemudian getah yang diperoleh ditambahkan dengan $\mathrm{NaCl}$ dengan tujuan untuk mengaktifasi enzim papain. Campuran yang diperoleh kemudian dikeringkan dengan bantuan cabinet drying. Kegiatan ini dilakukan di Laboratorium Fakultas Teknologi Pertanian Universitas Andalas. Dari hasil proses pengeringan diperoleh kristal papain kasar yang siap digunakan pada pembuatan pakan ikan lele. Enzim papain bekerja dengan cara pemecahan atau penguraian ikatan peptida pada protein. Penambahan papain pada formulasi akan berakibat pada tingkat kecernaan pakan yang semakin meningkat. Tingginya tingkat kecernaan dapat meningkatkan tingkat penyerapan asam amino ke dalam tubuh untuk pertumbuhan, sehingga pertumbuhan lele dapat berlangsung dengan cepat dalam waktu yang relatif singkat.

Untuk pembuatan pakan dilaksanakan langsung ditempat mitra melalukan budidaya ikan lele. Dalam pembuatan pakan dibutuhkan sebanyak 2,25\% papain kasar, tepung ikan sebanyak $39 \%$, tepung kedelai sebanyak $32,25 \%$, tepung jagung sebanyak $4,25 \%$, tepung dedak sebanyak $6,75 \%$, tepung terigu sebanyak 10\%, vitamin mineral mix sebanyak 4\%, serta CMC sebanyak 1,5\% (Gambar 1) dengan formulasi mengacu kepada penelitian yang dilakukan oleh Amalia, Subandiyono, Arini (2013). Formulasi di atas dicampur dengan air suhu $50^{\circ} \mathrm{C}$ sampai homogen. Adonan dicetak dengan menggunakan alat penggiling daging (Gambar 2) sehingga diperoleh pelet yang masih basah seperti pada Gambar 3a. Setelah pengeringan di bawah sinar matahari kurang lebih selama 3 hari, maka diperoleh pelet seperti Gambar 3b. Pelet yang dihasilkan memiliki bau yang hampir sama dengan pakan lele yang ada di pasaran namun bentuk yang dihasilkan belum seragam. Menurut Amalia, Subandiyono, Arini (2013), formulasi pakan tersebut memiliki kadar protein sebesar 30,22\%, kadar lemak 10,48\%, BETN 30,73\%, nilai energi 267,49 (kkal/g), dan rasio E/P 8,85 (kkal/g P).

Berdasarkan hasil perhitungan pembuatan pakan lele dengan penambahan enzim papain memerlukan biaya sebesar Rp. 8.000/kg nya, lebih murah dibandingkan dengan harga pakan yang dijual di pasaran (Rp. 12.000/kg). Kualitas pakan yang dihasil memiliki tekstur dan warna menyerupai pakan yang dijual di pasaran. Selain itu pakan yang dihasilkan juga mengapung dengan baik ketika ditebarkan di kolam. Dari kegiatan pelatihan pembembuatan pakan ikan lele mitra berharap untuk tahap berikutnya adanya pelatihan tentang pembuatan tepung ikan sehingga biaya untuk pembelian bahan baku masih dapat ditekan lebih rendah lagi. 


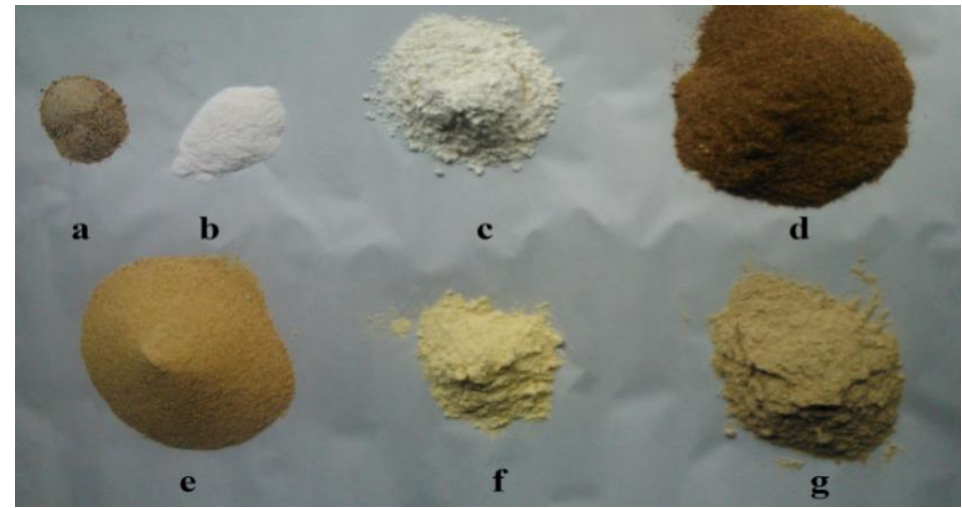

Gambar 1. Bahan yang digunakan dalam pembuatan pakan.

Papain (a), CMC (b), tepung terigu (c), tepung ikan (d), tepung jagung (e), tepung kedelai (f), dedak (g)

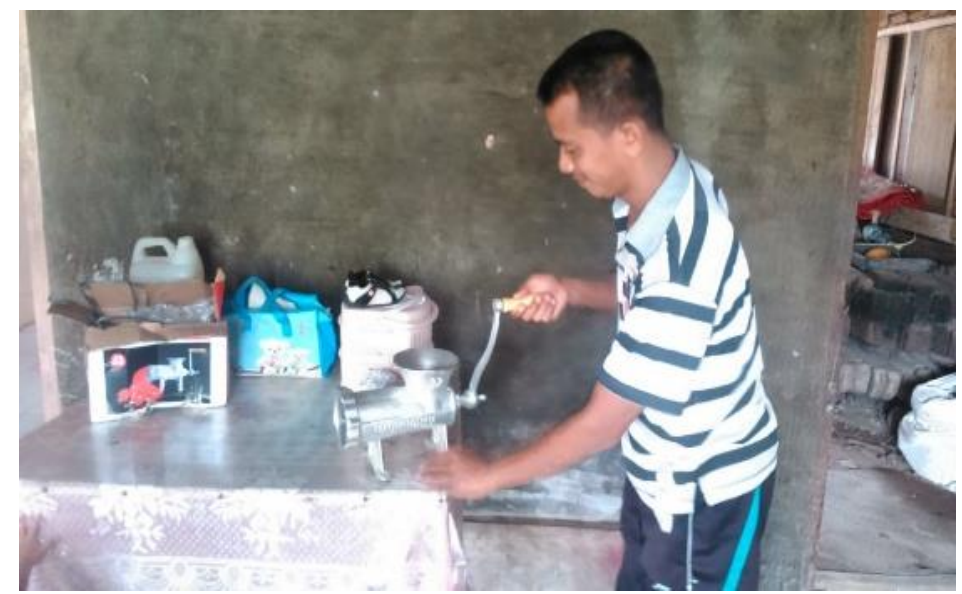

Gambar 2. Mitra sedang merakit alat pengiling daging

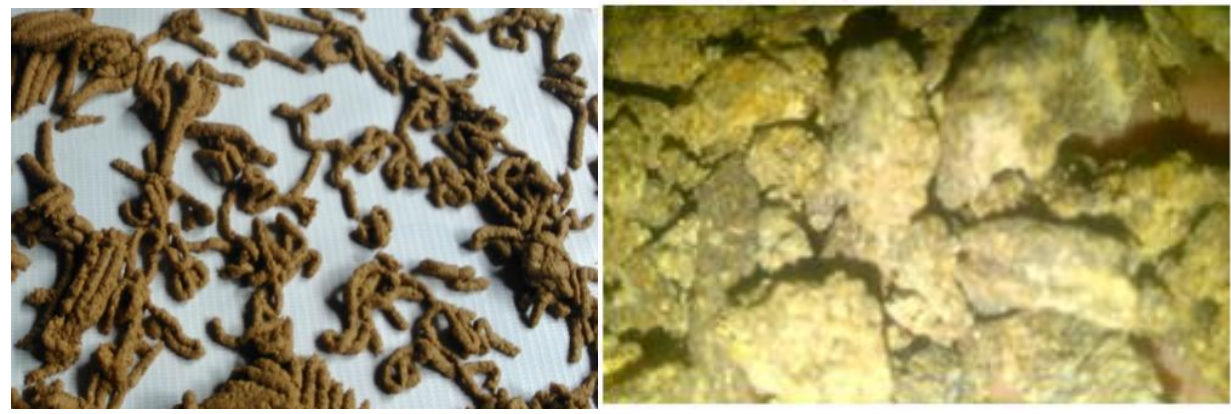

Gambar 3. Adonan pelet: masih basah setelah dicetak (a), setelah dikeringkan (b)

Nugget ikan adalah suatu bentuk produk olahan daging ikan yang terbuat dari daging ikan yang digiling kemudian dicetak dalam bentuk potongan empat persegi dan dilapisi dengan tepung berbumbu (battered dan breaded). Nugget ikan dikonsumsi setelah proses penggorengan rendam (deep fat frying). Pembuatan nugget lele yang dilakukan mengacu kepada metode Ismed, Huda dan Ismail, (2009). Bahan yang digunakan dalam pembuatan nugget ikan lele, antara lain sebanyak 65\% daging ikan lele yang sudah dihaluskan dan dipisahkan dari tulang dan kulit, tepung tapioka sebanyak 19\%, garam sebanyak 1\%, bawang putih sebanyak 0,6\%, merica sebanyak 0,4\%, serta air es sebanyak 14\% (Gambar 4). Semua bahan dicampur dan di diamkan selama 5 menit. Adonan dimasukan ke dalam loyang dengan ketebalan adonan $\pm 0,5 \mathrm{~cm}$, kemudian dikukus pada suhu $90^{\circ} \mathrm{C}$ selama 30 menit (Gambar 5). Dilakukan pemotongan dengan panjang dan lebar 1-1,5 cm. Nugget dilapisi denggan putih telur kemudian dilumuri dengan tepung panir. Nugget siap untuk digoreng dan jika ikan tidak langsung dikonsumsi dapat 
disimpan dalam freezer. Penampakan nugget yang telah digoreng dapat dilihat pada Gambar 6 . Menurut mitra binaan nugget yang dihasilkan memiliki rasa yang tidak kalah dibandingkan nugget ayam, disamping itu tekstur dan aromanya juga disukai.

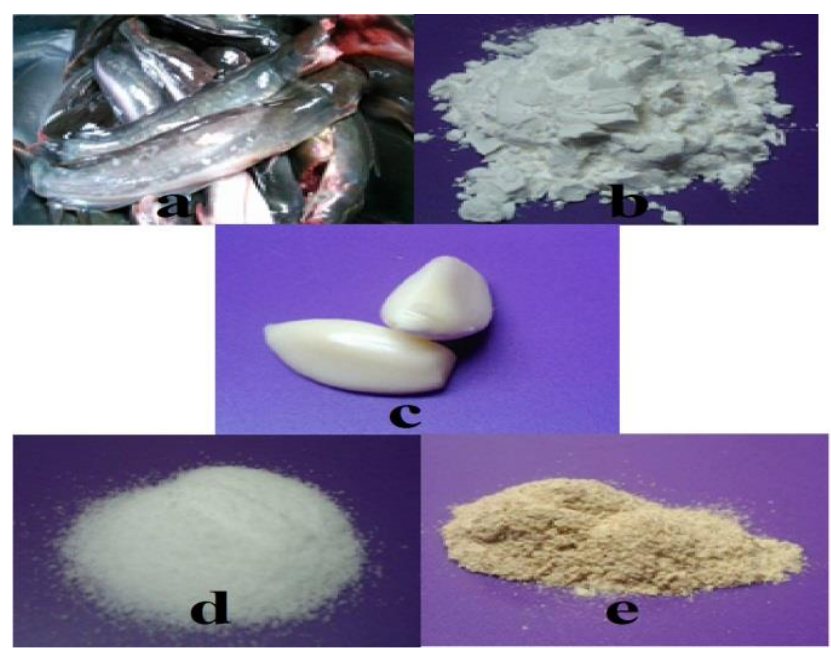

Gambar 4. Bahan yang digunakan dalam pembuatan nugget lele. Ikan lele (a), tepung tapioka (b), bawang putih (c), garam (d), merica (e)

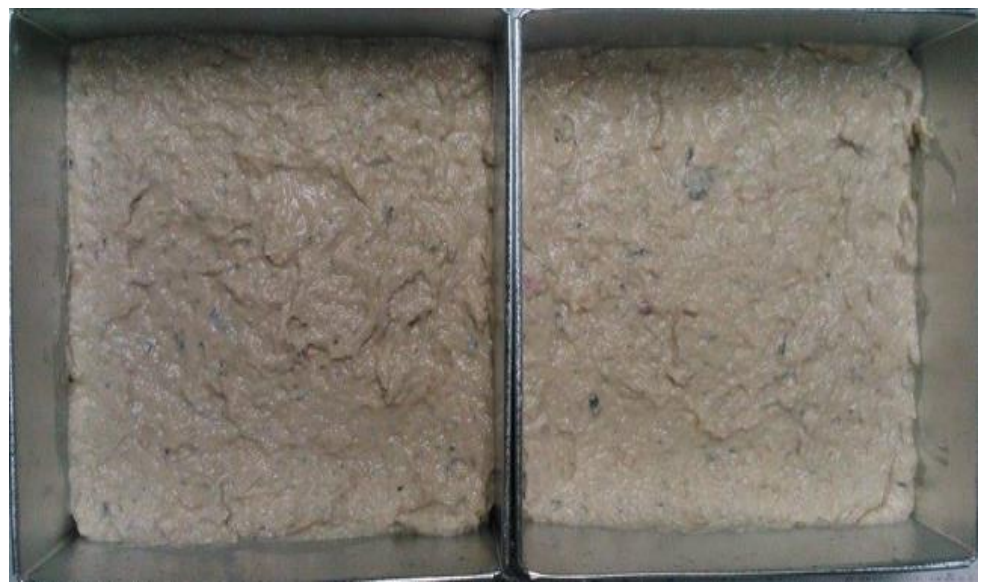

Gambar 5. Adonan yang terbentuk

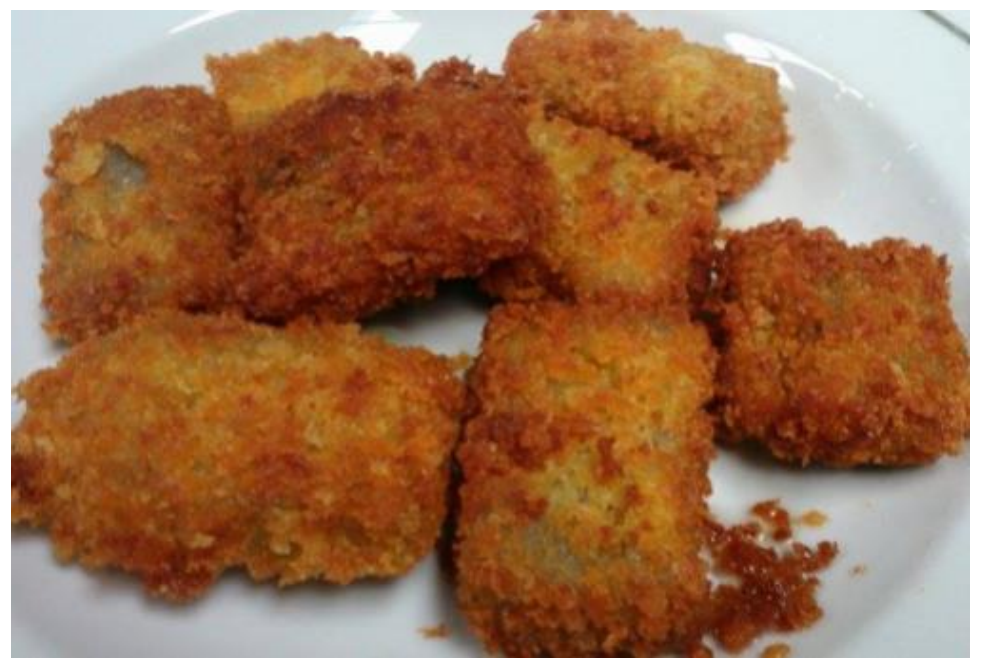

Gambar 6. Nugget yang telah digoreng 
Berdasarkan kegiatan monitoring dan evaluasi yang dilakukan dapat dilihat adanya peningkatan pemahaman mitra binaan dalam pengolahan pakan ikan lele dan pengolahan ikan lele menjadi nugget. Adapun indikator keberhasilan dapat dilihat seperti pada Tabel 1.

Tabel 1. Indikator Keberhasilan Program Pengabdian

\begin{tabular}{|c|c|c|c|c|c|}
\hline \multirow[t]{2}{*}{ No } & \multirow[t]{2}{*}{ Pertanyaan } & \multicolumn{2}{|c|}{$\begin{array}{c}\text { Pengolahan } \\
\text { Pakan Ikan Lele } \\
\text { dengan } \\
\text { Pemanfaatan } \\
\text { Enzim Papain } \\
(\%)\end{array}$} & \multicolumn{2}{|c|}{$\begin{array}{c}\text { Pengolahan } \\
\text { Nugget Ikan Lele } \\
\text { (\%) }\end{array}$} \\
\hline & & Ya & Tidak & Ya & Tidak \\
\hline 1 & Pernah mengikuti seminar/pelatihan serupa? & 0 & 100 & 0 & 100 \\
\hline 2 & $\begin{array}{l}\text { Apakah materi yang disampaikan telah sesuai } \\
\text { dengan yang diharapkan? } \\
\text { Apakah waktu penyelenggaraan pelatihan bagi }\end{array}$ & 100 & 0 & 100 & 0 \\
\hline 3 & $\begin{array}{l}\text { Bapak/Ibu mencukupi dalam memahami } \\
\text { materi pelatihan? }\end{array}$ & 70 & 30 & 80 & 20 \\
\hline 4 & $\begin{array}{l}\text { Dengan materi ini akan memudahkan saya } \\
\text { memberikan pemahaman dan menyampaikan } \\
\text { kepada kolega untuk mempraktekkan materi } \\
\text { pelatihan? }\end{array}$ & 85 & 15 & 90 & 10 \\
\hline 5 & $\begin{array}{l}\text { Dengan adanya materi pelatihan ini saya } \\
\text { tetarik mengembangkannya menjadi suatu } \\
\text { usaha? }\end{array}$ & 70 & 30 & 80 & 20 \\
\hline 6 & $\begin{array}{l}\text { Setelah mengikuti pelatihan ini apakah terjadi } \\
\text { peningkatan pemahaman Bapak/Ibu? }\end{array}$ & 90 & 10 & 100 & 0 \\
\hline 7 & $\begin{array}{l}\text { Apakah secara keseluruhan kegiatan pelatihan } \\
\text { ini terasa bermanfaat bagi Bapak/Ibu? }\end{array}$ & 100 & 0 & 100 & 0 \\
\hline
\end{tabular}

Dari Tabel 1, dapat dilihat bahwa terjadi peningkatan pemahaman mitra sebesar 90\% terkait dengan pelatihan pengolahan pakan ikan dengan memanfaatkan enzim papain, serta 100\% mitra merasa terjadi peningkatan pemahamannya dalam mengolah nugget ikan lele. Dari kedua pelatihan yang diberikan $100 \%$ mitra merasa memperoleh manfaat dari kegiatan tersebut. Kedepannya mitra binaan berharap adanya pendampingan dari perguruan tinggi dalam pengolahan produk hasil perikanan lainnya, seperti bakso ikan dan sosis ikan.

\section{KESIMPULAN}

Dari kegiatan ini dapat disimpulkan terjadi peningkatan pemahaman mitra binaan tentang pemanfaatan enzim papain dalam pembuatan pakan ikan lele sebesar $90 \%$ serta pengolahan produk ikan lele sebesar $100 \%$.

\section{DAFTAR PUSTAKA}

Amalia R, Subandiyono, Arini E. 2013. Pengaruh Penggunaan Papain terhadap Tingkat Pemanfaatan Protein Pakan dan Pertumbuhan Lele Dumbo (Clarias gariepinus). Jounal of Aquaculture Management dan Technology. Volume 2, Nomor 1. Hal 136-143. 
Ismed, Huda, N., and Ismail, N. 2009. Physicochemical and sensory quality of duck nuggets containing different types of flour. 11th ASEAN Food Conference, 21-23 October 2009, Bandar Seri Begawan, Brunei Darussalam.

Permata D.A, Ikhwan H, Aisman. 2016. Aktivitas Proteolitik Papain Kasar Getah Buah Pepaya dengan Berbagai Metode Pengeringan. Jurnal Teknologi Pertanian Andalas. 20(2):58-64.

Subandiyono dan S. Hastuti. 2010. Buku Ajar Nutrisi Ikan. Lembaga Pengembangan dan Penjaminan Mutu Pendidikan Universitas Diponegoro, Semarang. 